Principios

\title{
Filosofia e censura: uma reflexão na trilha d' $O$ passeio do cético
}

\author{
Philosophy and censorship: A reflection on the trail of The Skeptic's \\ Walk
}

do $10.21680 / 1983-2109.2021 v 28 n 57$ ID26157

\author{
Felipe Cordova \\ Universidade Federal do Paraná (UFPR) \\ 0000-0003-3719-5852 \\ felipeacordova@gmail.com
}

\begin{abstract}
Resumo: Em um ensaio que se tornaria clássico, Leo Strauss recolocou na ordem do dia a necessidade de se atentar para o que ele chamou de escrita nas entrelinhas, imperativo esquecido pela pesquisa histórica moderna, forjada num contexto em que a perseguição e a censura se encontravam já ausentes. O tipo de reflexão elaborado por Strauss, porém, já havia sido concebido pelos próprios autores modernos, que por vezes tematizaram sua escrita e os perigos envolvidos nessa atividade. Este trabalho toma como mote o discurso preliminar a $O$ passeio do cético, de Diderot, onde o autor reflete sobre a situação do escritor em meados do século XVIII para, a partir daí, desdobrar uma linha temporal que permite dimensionar o alcance dessa reflexão.
\end{abstract}

Palavras-chave: Iluminismo; Libertinismo erudito; Censura; Charron; Bayle; Diderot

\begin{abstract}
In an essay that would become a classic, Leo Strauss has put back on the agenda the need to pay attention to what he called writing between the lines, an imperative forgotten by modern historical research, which was forged in a context where persecution and censorship were already absent. The kind of reflection elaborated by Strauss, however, had already been conceived by modern authors themselves, who sometimes thematized their own writing and the dangers involved in this activity. This work takes as its motto the preliminary speech to Diderot's The Skeptic's Walk, in which the author reflects on the situation of the writer in the mid-eighteenth century and, from there, unfold a timeline that allows us to scale the scope of this reflection.
\end{abstract}

Keywords: Enlightenment; Erudite libertinism; Censorship; Charron; Bayle; Diderot

\section{INTRODUÇÃO}

Em sua recuperação da escrita e da leitura esotéricas, a partir de fins da década de 1930, Leo Strauss chamava atenção para o fato de que "a pesquisa histórica moderna, tendo surgido numa época em que a perseguição era mais uma débil lembrança que uma experiência vigorosa, reagiu contra, ou mesmo destruiu uma 
tendência anterior de ler nas entrelinhas dos grandes escritores, ou de conferir mais peso à sua concepção fundamental que às opiniões repetidas por eles com mais frequência" (Strauss, 1988, p. 32). A crer em Strauss, os textos produzidos no interior de um regime de perseguição exigiriam um tipo de leitura atenta aos cuidados que os escritores devem ter tido ao confeccioná-los, pois "a influência da perseguição sobre a literatura consiste precisamente no fato de que ela força os escritores que pretendem exprimir ideias heterodoxas a desenvolver uma técnica especial de escrita, o tipo de técnica que temos em mente quando falamos em escrever nas entrelinhas" (Strauss, 1988, p. 24).

Ora, essa reflexão foi feita já no século XVIII pelos próprios autores que se serviram dessa escrita nas entrelinhas e só precisou ser recuperada por Strauss no século XX porque, como ele mesmo afirma, havia sido esquecida pela pesquisa histórica moderna. Trataremos aqui de seguir a trilha de Diderot, expondo e desenvolvendo uma reflexão desse tipo encetada por ele no discurso preliminar a O passeio do cético. Diderot reflete aí sobre a condição do escritor em uma época de censura e perseguição, cedendo-nos a ocasião de desdobrar uma linha temporal que permitirá dimensionar o alcance dessa reflexão.

\section{O PASSEIO DO CÉTICO E A "MUDANÇA ESTRATÉGICA"}

Quando narrou, em um discurso preliminar, a discussão entre Aristo e Cleóbulo a respeito da publicação do manuscrito de $O$ passeio do cético, Diderot certamente estava preocupado em sopesar as pretensões e os riscos de sua recémcomeçada carreira intelectual, ${ }^{1}$ mas estava ao mesmo tempo pondo em perspectiva histórica a condição do escritor na França de meados do século XVIII, em especial a daquele que ousava pensar livremente o governo e a religião, os "temas sagrados nos quais não é permitido tocar" (Diderot, 1994, p. 74). Já se observou que o referido diálogo registra uma "mudança estratégica" ocorrida na metade do séc. XVIII francês, opondo à prudência e ao segredo dos libertinos eruditos, representados aqui por Cleóbulo, "a necessidade expressa pelo jovem Aristo de doravante publicar as obras que denunciam o mecanismo perverso que mantém os homens na opressão e na ignorância" (Seguin, s/d, p. 2), numa alusão ao início do Iluminismo propriamente dito. Se a visão de sobrevoo confirma essa narrativa em seu

\footnotetext{
1 Estima-se que a redação de O passeio do cético seja de 1747 (sobre o debate em torno dessa datação, cf. Gerhardt Stenger, Sur la chronologie des premières oeuvres de Diderot, in: Dix-huitième siècle, janeiro 1993). Até então, Diderot havia publicado (anonimamente) um único trabalho autoral, os Pensamentos Filosóficos, em junho de 1746, e redigido, ao fim do mesmo ano, um opúsculo Sobre a suficiência da religião natural, publicado apenas em 1772. Antes disso, traduziu obras inglesas sob encomenda, sobretudo para o livreiro Antoine-Claude Briasson, além de publicar uma tradução comentada de An Inquiry Concerning Virtue and Merit, de Shaftesbury, em 1745.
} 
conjunto, uma análise de suas etapas e das trajetórias particulares dos autores, conquanto não a desminta, todavia mostrará que ela não é assim tão linear.

Antes de mais nada, será oportuno repassarmos o diálogo que nos serve de mote. Quem nos interpela é Aristo, um militar sem grandes ambições literárias, suposto autor de um conto alegórico intitulado O passeio do cético ou As alamedas, e que se vale de um discurso preliminar para nos relatar as circunstâncias de sua redação. Somos então apresentados a Cleóbulo, por quem Aristo nutre uma forte amizade. Trata-se de um homem já de meia idade que, depois de ter "visto o mundo e se desgostado dele" (Diderot, 1994, p. 71), retirou-se para uma casa afastada na província, à qual se chega passando antes por "um lugar que não é nem bosque, nem prado, nem jardim; é uma reunião de tudo isso" (ibid., p. 72), e onde ele recebe um grupo seleto de amigos. Nessa espécie de jardim de Epicuro, Aristo se entreteve repetidas vezes ouvindo os discursos de Cleóbulo. O jovem militar conta ter logo reparado que os discursos proferidos pelo amigo possuíam certa ordem e que "os assuntos que ele introduzia eram quase sempre análogos aos objetos que ele tinha sob os olhos" (ibidem), e aduz então vários exemplos dessa "espécie de filosofia local" (ibid., p. 73). O principal deles, que motivou Aristo a tomar da pena para registrá-lo, foi um discurso enunciado enquanto caminhavam por uma parte desse cenário que se assemelhava a uma estrela, em cujo centro se entrecruzavam várias alamedas: "em menos de duas horas que passamos a caminhar da alameda dos espinhos à dos castanheiros, e da alameda dos castanheiros ao jardim que a ladeia, ele esgotou a extravagância das religiões, a incerteza dos sistemas da filosofia e a vaidade dos prazeres do mundo" (ibidem).

Aristo havia feito circular, sob forma manuscrita e apenas entre pessoas de confiança, o discurso de Cleóbulo. Logo, porém, as cópias se multiplicaram e, como era de praxe em se tratando de literatura clandestina, surgiram versões em que a obra era mais ou menos desfigurada. Desconfortável com essa situação e com medo de que Cleóbulo acabasse sabendo por terceiros dessa sua indiscrição, Aristo decide solicitar ao amigo a permissão para publicar o texto. A resposta de Cleóbulo contém os elementos-chave que permitem aproximá-lo da figura histórica do 'libertino erudito', em especial no que se refere à prudência e ao segredo:

Eu não vos culpo por trabalhar para esclarecer os homens; é o serviço mais importante que alguém poderia se propor a lhes render, mas é também aquele que não lhes será jamais rendido. Apresentar a verdade a certas pessoas é (...) introduzir um raio de luz em um ninho de corujas; só serve para ferir seus olhos e provocar seus gritos. Se os homens fossem ignorantes apenas por não haverem aprendido nada, talvez se pudesse instruí-los; mas sua cegueira é sistemática. Aristo, não tendes relação apenas com gente que nada sabe, mas com gente que nada quer saber. Pode-se abrir os olhos daquele cujo erro é involuntário; mas por onde atacar aquele que levanta a 
guarda contra o senso comum? Não esperai, pois, que vossa obra sirva aos outros; mas temei que ela não prejudique infinitamente a vós mesmo. A religião e o governo são temas sagrados nos quais não é permitido tocar. Aqueles que manobram o timão da Igreja e do Estado ficariam muito desconcertados se tivessem que nos dar um bom motivo para o silêncio que nos impõem; mas o mais seguro é obedecer e se calar, a menos que se tenha encontrado nos ares algum ponto fixo fora de seu alcance, de onde se pudesse anunciar-lhes a verdade (Diderot, 1994, p. 74).

O discurso de Cleóbulo, portanto, contém não apenas o tema da prudência em relação à censura e à perseguição pelas autoridades - que se desdobra imediatamente no tópico da dissimulação - , mas faz também menção a um tema que, entre os libertinos eruditos, ia de par com o primeiro: o pessimismo quanto à possibilidade de ilustrar os homens, devido à sua "cegueira sistemática". Um breve recuo até as primeiras décadas do século XVII, época do surgimento da literatura que hoje conhecemos como libertina, poderá dar mais concretude à reflexão na qual Diderot nos engaja.

\section{LIBERTINAGEM E DISSIMULAÇÃO}

Com efeito, não é difícil encontrar prescrições de prudência, assim como o pessimismo que a acompanha, entre os 'libertinos eruditos'. 2 Eles estão presentes, por exemplo, nos Quatro diálogos feitos à imitação dos antigos, de François de La Mothe Le Vayer. Na carta do autor que antecede os diálogos, publicados em 1630,3 ele alerta para o fato de que

a liberdade de meu estilo, desprezando todo constrangimento, e a licença de meus pensamentos puramente naturais são hoje mercadoria de contrabando que não devem ser expostas ao público. (...) A obscuridade do futuro me faz ignorar se um dia chegará o tempo em que essas coisas possam agradar; mas sei bem que para o presente elas seriam extremamente desagradáveis. (...) Zombemos do favor de uma multidão tola e, no justo desprezo a um século ignorante e perverso, gozemos dos verdadeiros e sólidos contentamentos de nossas conversas privadas (Le Vayer, 1633, p. 3).

Se, por um lado, faz referência à recepção incerta da posteridade, La Mothe Le Vayer aí constata, por outro, a certeza da má recepção do presente. Sem entrar-

\footnotetext{
2 A categoria de 'libertinismo erudito', vale lembrar, foi forjada por René Pintard em um estudo clássico intitulado Le Libertinage érudit dans la première moitié du XVIIe siècle, de 1943. Ele a utilizou para designar sobretudo a tétrade composta por François de La Mothe Le Vayer, Gabriel Naudé, Pierre Gassendi e Élie Diodati (Cf. René Pintard, Le Libertinage érudit dans la première moitié du XVIIe siècle. Genève, Paris, Slatkine, 1983). Com ela, Pintard qualifica o termo genérico de libertinagem ou libertinismo, cujo uso polêmico pela apologética cristã não distinguia a libertinagem do espírito da licenciosidade de costumes. A pesquisa posterior, no entanto, tem problematizado e frequentemente colocado em questão a pertinência da categoria cunhada por Pintard (cf. JeanPierre Cavaillé, 2007; 2013; e Françoise Charles-Daubert, 1998).

3 Os Quatro diálogos foram impressos clandestinamente sob o pseudônimo de Orasius Tubero, e com indicações falsas de data e local: Frankfurt, 1506. A tiragem da impressão parece ter sido bastante reduzida, indicando que o livro se destinava a circular entre os iniciados e pessoas de confiança. Os mesmos procedimentos foram adotados para a publicação, no ano seguinte, de outros Cinco diálogos.
} 
mos no mérito dos fundamentos filosóficos do pessimismo de Le Vayer, parece factível pensar que essa certeza se devia em boa medida à contundência incontornável de um acontecimento recente: em 1623, o poeta Théophile de Viau, autor de versos licenciosos publicados na coletânea Parnasse Satyrique, havia sido condenado à fogueira. A sentença seria executada em efígie, em agosto, pois Théophile conseguira escapar e se esconder no castelo de Chantilly. No mês seguinte, contudo, ao tentar fugir para a Inglaterra, foi detido junto à fronteira, e em seguida transferido para a Conciergerie, em Paris, com emprego ostensivo de forças militares em sua escolta. Aí permaneceria por quase dois anos, ao longo dos quais seu processo se desenrolava lenta e minuciosamente, até que a pena fosse comutada em banimento, em setembro de 1625 . Com a saúde arruinada pelos tempos de encarceramento, morreria cerca de um ano depois.

Théophile havia sido o nome maior da geração de 1620, por vezes referida como a "primeira libertinagem" (Adam, 1964, p. 7). Há relatos dando conta de casos de irreligião nas adjacências da corte francesa desde o século XVI, mas tratava-se então de ocorrências isoladas, excepcionais e, em todo caso, discretas. Por volta de 1620 , no entanto, parte considerável da jovem nobreza parisiense passa a nutrir o hábito de se reunir nos cabarets d'honneur, ${ }^{4}$ para aí cantar "versos blasfematórios, sem distinguir revolta contra a religião e licenciosidade nos costumes" (ibid., pp. 7-8). O escândalo ganha proporções inéditas com a publicação, em novembro de 1622, de uma obra coletiva reunindo mais de uma centena de peças bastante diversas em forma e conteúdo, indo do satírico ao obsceno. Embora sem gozar de um privilégio de publicação, ${ }^{5}$ os editores do Parnasse des poètes satyriques não tomam os cuidados que de costume acompanhavam uma impressão clandestina, ${ }^{6}$ e a obra acaba por representar uma afronta sem precedentes às autoridades civis e religiosas. Os poemas de Théophile, constando de sua assinatura, abrem o volume e o incriminam irremissivelmente.

\footnotetext{
4 Denominação irônica para as tavernas de má reputação onde se reuniam os chamados libertinos.

5 A regulação do sistema editorial pela monarquia francesa, tendo como órgão responsável a Direction de la librairie, determinava que toda obra passasse por uma censura prévia à publicação, após o que ela receberia ou não a aprovação dos censores - normalmente doutores da Sorbonne - e, por fim, o privilégio do rei. “O privilégio operava em três níveis na indústria editorial: o livro em si era privilegiado (a ideia moderna de direito autoral ainda não existia, a não ser na Inglaterra); o livreiro era privilegiado (enquanto membro de uma corporação, ele gozava do direito exclusivo de participar do comércio livreiro); e a corporação era privilegiada (enquanto uma corporação exclusiva, ela se beneficiava de certos direitos, notavelmente da isenção da maior parte das taxas)" (Darnton, 2014, p. 29).

60 volume conhecido como Parnasse satyrique reunia, na verdade, dois livros: o primeiro, propriamente intitulado Parnasse des poètes satyriques, é uma coletânea de poemas atribuídos aos jovens libertinos da época; o segundo, intitulado Quintessence satyrique, é uma reunião de poemas "retirados das obras secretas dos autores mais destacados de nosso século” (Le Parnasse des poètes satyriques, 1622), incluindo autores então já falecidos, como Berthelot. "A segunda parte do volume, a Quintessência satírica, levava o nome de Antoine Sommaville [como editor], no Palais, galeria dos livreiros. Todo mundo podia, se quisesse, saber que o livreiro Estoc havia impresso a primeira parte" (Adam, 1964, p. 33). Ambas exibiam a data de 1622.
} 
O padre François Garasse é quem acende a polêmica, lançando-se imediatamente à redação d'A curiosa doutrina dos belos espíritos deste tempo, ou que pretendem sê-lo, que seria publicada em agosto de $1623 .{ }^{7} \mathrm{Na}$ obra de mais de mil páginas, repleta de ofensas e ataques pessoais, Garasse elenca o que supõe serem as oito máximas dos libertinos - compondo os oito livros do volume -, tratando, entre outras coisas, dos temas que nos interessam mais de perto: o segredo, a dissimulação e a distinção entre espíritos fracos e fortes.

Garasse busca apontar a origem das ideias que teriam inspirado os jovens libertinos, e indica a doutrina de Pierre Charron como sua principal fonte. Charron, segundo ele, teria distinguido três tipos de espírito entre os homens: 0 primeiro é o dos espíritos baixos, próprios da plebe; são os estúpidos, que se deixam levar por preconceitos e superstições, e que são conduzidos como uma manada, sem nenhum questionamento; nesse grupo estaria enquadrada a maioria dos cristãos. O segundo tipo é o dos espíritos comuns, de indivíduos "um pouco mais refinados que os primeiros" (Garasse, Doctrine curieuse, in: Adam, 1964, p. 32), que percebem a estupidez da superstição, mas que não possuem a força interior para romper com a servidão e acabam se engajando nas funções do Estado, da política ou da polícia. O terceiro tipo, por fim, é o dos espíritos desviados, "que não seguem o grande caminho repisado pela plebe" (ibidem); eles são exceção em cada época, como foram Sócrates entre os gregos, Cícero entre os latinos e Charron entre os franceses. Não sem certa ironia, Garasse sugere que, para esses espíritos, "a maior sabedoria que há no mundo é não tomar o grande caminho, mas seguir veredas apartadas, não julgar jamais segundo o senso comum, seguir sempre pelas margens, enviesar e tomar um novo rumo, tanto em matéria de negócios, quanto de ciências e de religião" (ibidem).

Passando em seguida a seu alvo principal, Garasse afirma que "um bando de ateus" se apropriou da doutrina de Charron, apenas renovando-lhe a terminologia e classificando agora os espíritos em mecânicos, para designar os que seguem a religião e temem a Deus; nobres, em referência aos indivíduos que, embora não cheguem ao ponto extremo da ruptura, veem com desconfiança as opiniões comuns; e transcendentes, referindo-se aos que, como afirma Garasse, carregando novamente no tom irônico, "veem cento e cinquenta braças por sobre os outros, que se perdem nas nuvens, que fazem desenhos sublimes, que vivem a seu bel pra-

\footnotetext{
7 François Garasse (1585-1631), padre jesuíta, escreveu ainda uma Apologie du Père François Garassus, de la Compagnie de Jesus, pour son livre contre les Atheistes \& libertins de nostre siecle, publicada em 1624, defendendose das críticas dos defensores de Charron, e La Somme Théologique des veritez capitales de la Religion Chrestienne, de 1625. A Doutrina Curiosa foi, segundo Popkin, "a resposta ao ceticismo que realmente lançou a contraofensiva" à retomada cética moderna (Popkin, 2003, p. 100).
} 
zer, que contentam a doce natureza, que não são cruéis inimigos de seus sentidos, que esvoaçam pelos cabarets d'honneur' (ibid., p. 39). Assim, a primeira das máximas desses 'belos espíritos' transcendentes é, na formulação de Garasse, a de que "existem poucos bons espíritos no mundo, e os tolos, quer dizer, a maior parte dos homens, são incapazes de nossa doutrina. Portanto, não se deve falar dela abertamente, mas em segredo e entre espíritos confidentes e cabalistas" (ibid., p. 41).

São precisamente esses que se denominam transcendentes os que Garasse tem na conta de libertinos: "chamo de libertinos nossos beberrões, moscas de taberna, espíritos insensíveis à piedade, que não possuem outro deus que seu próprio ventre, que estão alistados naquela maldita confraria chamada Confrérie des bouteilles" (ibid., p. 40). São nobres ou agregados da corte que levam uma vida despreocupada e desregrada, desprezando a religião sobretudo por desejarem se entregar aos prazeres mundanos, mas que "não estão de todo embrutecidos pelo vício", nisso diferindo dos ateus propriamente ditos: "por isso ficam bem definidos quando os chamamos de libertinos, pois é como se disséssemos aprendizes do ateísmo" (ibidem). É provável que Garasse tenha tido o cuidado de preservar certos filhos da nobreza, outorgando-lhes uma condição ainda passível de salvação. A 'doutrina' pela qual eles se sentem atraídos, no entanto, é condenada sem apelação.

Théophile, bem como todos que "publicam em sonetos suas execráveis ofensas", estaria num estágio "mais avançado em malícia”, o dos ímpios e ateus, pois, adverte Garasse, "existem vários graus de ateísmo" (ibid., p. 41). Se para os libertinos ainda há alguma esperança de salvação, em relação aos ateus já não resta o que fazer, de modo que "não se ousaria refutá-los ponto por ponto, com medo de ensinar seus vícios e fazer corar a brancura do papel" (ibidem). Desse modo, o livro de Garasse se dirige aos libertinos como quem fala a jovens desviados que ainda podem ser salvos, e ataca constantemente os ateus, como aquilo que os libertinos estão em vias de se tornar. Théophile é, nesse sentido, o exemplo negativo por excelência, donde a severidade de sua condenação: era preciso que sofresse uma punição exemplar.

\section{INTUS UT LIBET, FORIS UT MORIS EST}

A exposição feita por Garasse da 'doutrina' dos libertinos é obviamente uma caricatura. Se mais não houvesse, simplesmente porque algo como uma 'doutrina libertina' sequer existia, já que os termos libertino e libertinagem eram utilizados com intuito polêmico, ou seja, acusava-se de libertinagem, mas ninguém a reivin- 
dicava para si. ${ }^{8}$ Ainda assim, é inegável a perspicácia do padre Garasse ao atribuir a Charron - e, em menor medida, a Vanini - a paternidade do 'movimento libertino', conseguindo assim fixar minimamente uma doutrina a ser combatida. Embora carregue um pouco nas tintas, o quadro pintado por Garasse de uma ordenação hierárquica dos espíritos por parte de Charron, classificando-os em fracos e fortes, não é propriamente uma inverdade.

No prefácio à segunda edição de Da Sabedoria, Charron expõe claramente sua concepção da tripartição da sabedoria:9 "podemos dizer que há três tipos e graus de sabedoria, a divina, a humana e a mundana, correspondendo a Deus, à natureza pura e íntegra e à natureza viciada e corrompida" (Charron, 1827, p. XXXVI). Não há consenso sobre o que seja a sabedoria, mas homens comuns, filósofos e teólogos, os "três estágios e classes do mundo", abordam-na cada um à sua maneira: "os dois últimos procedem por ordem, regras e preceitos, os primeiros confusamente e de modo muito imperfeito" (ibidem). Todos eles eventualmente falam de todos os tipos de sabedoria, mas só podem falar de modo apropriado daquela que lhes corresponde: "o homem comum, isto é, o mundo, [fala] da sabedoria mundana; o filósofo, da humana; e o teólogo, da divina” (ibidem). Essa divisão é apresentada no prefácio a fim de determinar com precisão o escopo do livro. Ficam excluídos os dois extremos: não se falará aí da sabedoria mundana, a mais baixa das três, a não ser para condená-la; a sabedoria divina, que é a mais elevada, deve ser objeto de um discurso teológico, como o de suas próprias obras de apologética cristã; "do que se segue que é da sabedoria humana que nosso livro trata" (ibid., p. XXXVIII).

Note-se que o sábio ou filósofo de que trata Charron, ao menos no que se refere ao tipo de sabedoria que toma por objeto, não se situa no topo de uma hierarquia espiritual, mas em posição intermediária; e, do ponto de vista das qualidades de seu espírito, equipara-se ao teólogo. A verdadeira distinção, como veremos, é entre espíritos fracos (ou comuns) e fortes, e os graus intermediários entre

\footnotetext{
8 “O libertino é então aquele que se opõe. E a libertinagem, explica René Pintard, 'recobre todo o inventário de opiniões, tendências ou comportamentos que se desviam das crenças ensinadas pelo magistério eclesiástico e aceitas pelo comum dos fiéis'. Jean-Pierre Seguin é mais rápido: 'a etiqueta serve para englobar tudo o que se nega polemicamente'. O termo funciona como uma arma e é utilizado num contexto de tensões e de conflitos" (Michel Delon, 2000, p. 24).

9 Pierre Charron (1541-1603), após uma tentativa malfadada na advocacia, foi homem da Igreja, cônego de Condom, e enquanto tal escreveu obras de apologética católica como o tratado As três verdades contra os ateus, idólatras, judeus, maometanos, heréticos e cismáticos, publicado pela primeira vez em 1593, e os Discursos cristãos, de 1601. A obra que o celebrizou - para o bem e para o mal -, no entanto, foi Da sabedoria, cuja primeira versão veio a público em 1601, impressa em Bordeaux 'com privilégio do Rei'. A forte reação ocasionada pelo livro levouo a elaborar uma segunda edição, revista e ampliada, que ele contudo não viu publicada, já que veio à luz em Paris apenas em 1604, um ano após sua morte. Charron alega ter "explicado, esclarecido, adocicado nesta segunda edição" várias coisas que "poderiam parecer muito cruas e curtas, rudes e duras aos simples” (Charron, 1827, p. LIX).
} 
os dois. Não há então oposição do religioso ao ateu. Isso porque aquela distinção se dá já no quadro da sabedoria humana, a qual, por sua vez, pressupõe uma dissociação entre a moral religiosa e uma moral laica. Antes mesmo de ser cristão ou ateu, o homem é um ser natural: "a filosofia é a irmã mais velha da teologia, como a natureza o é em relação à graça, e o natural em relação ao sobrenatural” (ibid., p. XL). O filósofo-sábio de Charron não é ateu nem se opõe à religião, como Garasse sugeria; ele apenas se atém a uma sabedoria humana, secularizada, deixando as questões divinas para o teólogo.

A sabedoria humana, eminentemente prática, fica então nitidamente demarcada em relação à sabedoria divina divisada pelos teólogos, mesmo ao que nela há de prático. Enquanto os filósofos tratam da vida prática "expressamente como seu verdadeiro objeto, seu assunto formal e próprio, pois eles se ocupam do que pertence à natureza e ao fazer", a teologia "se lança mais alto, atém-se e se dedica às virtudes infusas, teóricas e divinas, quer dizer, à sabedoria divina e à crença” (Charron, 1827, p. XXXIX). Tem-se com isso, de um lado, uma moral laica fundada na natureza humana e, de outro, a fé e a teologia como regramento moral atinente sobretudo ao "bem e à saúde eternos de cada um" (ibid., p. XL). Trata-se, no fundo, da dissociação entre duas jurisdições diferentes, como fica claro a partir da seguinte declaração de Charron: "Se eu tivesse me proposto a instruir para a clausura e a vida conciliária, quer dizer, para a profissão dos conselhos evangélicos, seria preciso seguir, ad amussim, as opiniões dos teólogos; mas nosso livro instrui para a vida civil, e forma um homem para o mundo, quer dizer, para a sabedoria humana, e não divina" (Charron, 1827, p. XLII).

Feita essa ressalva, é forçoso reconhecer que a distinção estabelecida por Charron entre espíritos fracos e fortes, justamente em função das vias de acesso e dos impedimentos à sabedoria humana, não se distancia muito da descrição de Garasse. No prefácio, Charron antecipa que há dois meios de se chegar à sabedoria humana, objeto do livro. O primeiro é, por assim dizer, uma predisposição natural para a sabedoria, e inclui não só as características inatas do indivíduo, mas os primeiros cuidados que recebe, "a partir do que se diz que alguém é bem ou mal nascido, quer dizer, bem ou mal formado e disposto para a sabedoria" (ibid., pp. XLVIXLVII). O segundo meio, tão raro quanto o primeiro, é o estudo da filosofia. Não, porém, de toda a filosofia, mas da moral, que é "a verdadeira ciência do homem" e que "ensina a bem viver e a bem morrer, que é tudo" (ibid., p. XLVIII).

De modo correspondente, existiriam dois tipos de impedimento à sabedoria, um natural e outro adquirido; são os dois descaminhos da razão, que não deixam de ser caminhos ou meios para a loucura, o contrário da sabedoria. O primeiro, 
natural, provém de um desvio na organização do indivíduo, cujo cérebro pode ser muito mole e úmido, tornando o espírito "estúpido, fraco, pouco capaz, raso, rebaixado, obscuro, tal como é a maior parte do comum" (ibid., p. XLIX); ou excessivamente quente, ardente e seco, deixando o espírito louco, audacioso, vicioso. "Essas são as duas extremidades, estupidez e loucura, água e fogo, o chumbo e o mercúrio, impróprias à sabedoria, que requer um espírito forte, vigoroso e generoso, e ainda assim doce, suave e modesto" (ibidem). O segundo impedimento, adquirido, consiste numa instrução nula ou inadequada. Charron se refere aqui sobretudo às ideias fixas que fanatizam o indivíduo e ao tipo de "prevenção obstinada [decorrente] de certas opiniões, das quais o espírito se inunda e assume fortemente a tintura; e assim se torna inapto e incapaz de ver e encontrar algo melhor, de se elevar e enriquecer" (ibid., p. L).

No capítulo XLV de Da Sabedoria, entretanto, Charron aborda a questão com mais detimento, e é então que aparece a classificação dos espíritos em três níveis: fracos, medíocres e superiores. Depois de tratar, nos capítulos precedentes, da "diferença e desigualdade dos homens em geral" e de uma primeira diferença particular, atinente à variedade advinda da "diversidade de climas e temperaturas", no capítulo XLV Charron se ocupa de uma "segunda distinção e diferença mais sutil dos espíritos e suficiências dos homens". ${ }^{10}$ Existem, de acordo com esta última, "três tipos de pessoas no mundo, que são como três classes ou graus de espíritos" (Charron, 1827, p. 334). A primeira e mais baixa é composta por espíritos fracos e rasos, de capacidade inferior, "nascidos para obedecer, servir e serem conduzidos" (ibidem). É a classe mais numerosa e constitui o que à época se denominava $o$ comum, ao qual Charron por vezes se refere também como popular.

Em seguida, em número significativamente menor, estão os que compõem uma classe intermediária, homens de juízo medíocre. Em relação aos espíritos mais baixos, eles possuem a vantagem de manifestar certa suficiência, ciência e habilidade, e por isso ocupam posições de comando na sociedade; e, como no interior dessa classe há uma grande diversidade de graus, os mais hábeis dentre eles governam o mundo. São desprovidos, todavia, de um espírito suficientemente penetrante para ir contra o que é comum, para relativizaro que é apresentado como verdade no contexto em que vivem, o que, como veremos, caracterizará o sábio. ${ }^{11}$

10 Suficiência aqui tem o sentido de capacidade intelectual (Cf. Suffisance, in: Littré, 1873-1874).

11 É digno de nota o fato de que Charron inclui Aristóteles entre os espíritos medíocres. "Essa gente [os espíritos medíocres] é da escola e da corrente de Aristóteles, afirmativos, positivos, dogmáticos, que se atêm mais à utilidade que à verdade, ao que é próprio ao uso e ao trânsito do mundo que ao bom e verdadeiro em si” (Charron, 1827, p. 335). O antiaristotelismo de Charron, manifesto em diversas passagens de Da Sabedoria, teve importante repercussão na filosofia francesa da primeira metade do século XVII: "Pierre Gassendi afirma no prefácio de sua 
Por fim, a classe mais elevada é a dos espíritos fortes. Eles são em número ainda mais reduzido que o dos espíritos medíocres, e se caracterizam por, ao contrário dos espíritos de classes inferiores, não receberem passivamente o que lhes vêm do exterior. Em vez disso, submetem tudo ao seu juízo e, se não encontram elementos suficientes para fazê-lo com segurança e clareza, optam por suspender seu julgamento. ${ }^{12}$ Daí resulta, como indicávamos acima, uma capacidade de relativizar o que os espíritos baixos e medianos entendem como dado. Ao passo que os espíritos medíocres "não olham além do lugar onde se encontram; pensam que em todo lugar é assim, ou deve ser; que se é diferente, é por uma falha ou porque são bárbaros" (Charron, 1827, p. 334), os sábios "não se contentam com ouvir dizer, não se detêm em opiniões comuns e recebidas, não se deixam ganhar e preocupar pela crença pública, da qual eles não se admiram, sabendo que há muito folclore, falsidades e imposturas recebidas no mundo com aprovação e aplauso, às vezes com adoração e reverência pública" (Charron, 1827, p. 335).

Para os fins perseguidos por nossa investigação interessa sublinhar o fato de que a sabedoria charroniana funciona aqui como um filtro capaz de reter o burburinho vindo do mundo, ${ }^{13}$ criando para os sábios um espaço de silêncio interior, no qual "examinam todas as coisas propostas, sondam cuidadosamente e buscam, sem paixão, pelas causas, motivos e motores, até a raiz" (ibidem). Esse vácuo criado pela sabedoria é o que protege o sábio dos mecanismos de assentimento a que estão submetidos todos os homens comuns.

Isso não significa, porém, que o sábio seja um rebelde ou um dissidente da sociedade. Pelo contrário, ele respeita os usos e costumes da comunidade em que vive, tanto quanto qualquer outro. Entretanto, não o faz por convicção. Descrevendo os espíritos medíocres, Charron observa que eles "se assujeitam às opiniões e leis municipais do local onde se encontram desde que nasceram, não apenas por observância e pelo uso, o que todos devem fazer, mas de coração e alma" (ibid., p. 334). O sábio, contudo, dissocia sua vida interior, em que empreende a busca da verdade livre de constrangimentos, do mundo exterior, no qual ele age em acordo com o costume, "vivendo exteriormente como todos, segundo as leis, costumes e cerimônias do país em que está, sem ofender a ninguém, portando-se tão pru-

\footnotetext{
primeira obra, os Exercícios paradoxais contra os aristotélicos, que a leitura do seu 'querido Charron' lhe deu coragem para rebelar-se contra a autoridade de Aristóteles” (Maia Neto, Apresentação, in: Charron, 2005, p. 10). 12 O ceticismo é uma característica nuclear do sábio, tal como descrito por Charron. Em Da Sabedoria o autor mobiliza certo pirronismo - recebido de Montaigne - tanto para uma crítica da teoria aristotélica do conhecimento, no segundo tomo, quanto para conjugá-lo a uma teologia negativa e conformar assim um pirronismo católico, por cuja via o sábio é liberado de todas as opiniões e falsas verdades e pode então aceitar a religião apenas pela fé (cf. Popkin, 2003, pp. 57-61).

13 “Os [espíritos] do meio produzem todo o barulho e as disputas que há no mundo, presunçosos, sempre agitados e agitando" (Charron, 1827, p. 336).
} 
dente e discretamente quanto possível em todos os assuntos, seguindo sempre reto, firme, alegre e contente consigo mesmo, esperando pacificamente tudo o que pode ocorrer, e a morte ao fim" (Charron, 1827, pp. XLII-XLIII).

Essa disjunção entre as vidas espiritual e exterior, contudo, não deve ser compreendida como dissimulação, no sentido pejorativo que hoje conferimos ao termo e que Garasse buscou imputar-lhe, identificando-o à falsidade. ${ }^{14}$ Charron recomenda aos sábios a prudência e a discrição a fim de evitar aborrecimentos, pois "como eles não concordam com o comum quanto às opiniões, veem mais claro, penetram mais longe e não são tão frívolos, recebem a suspeita e a má estima dos outros, que são em número muito maior e os têm por excêntricos e filósofos" (ibid., p. 336).

É, enfim, num tom de apelo à tolerância que Charron finaliza o prefácio à segunda edição de Da Sabedoria, recorrendo à autoridade do apóstolo Paulo para legitimar a dissociação entre o que é 'questão externa', de um lado, e a vida interior do indivíduo, sua por direito, de outro:

Nada convém mais à natureza que a diversidade. O divino sábio São Paulo põe-nos em liberdade por estas palavras: que cada um abunde em seu sentido, e que ninguém julgue ou condene aquele que age diferente e é de opinião contrária; e o diz em matéria bem mais forte e sensível, não em questão externa, onde dizemos que é preciso se conformar ao comum e ao que é prescrito pelo uso; mas em relação à religião, isto é, à observância religiosa das carnes e dos dias. Porém, toda minha liberdade e ousadia se refere apenas aos pensamentos, juízos, opiniões, os quais não dizem respeito a ninguém além daquele que as tem por direito (Charron, 1827, pp. LVIII-LIX).

Eis lançadas, assim, as bases de uma legitimação da dissimulação e do segredo. Se os libertinos do Marais não seguiram à risca as recomendações de Charron e afrouxaram os cuidados no tratamento sigiloso de ideias heterodoxas, como foi o caso com a publicação do Parnasse Satyrique, a condenação exemplar de Théophile de Viau fazia novamente soar o alarme da intolerância, e ele não seria negligenciado pelos libertinos eruditos. ${ }^{15} \mathrm{Na}$ esteira de Charron, eles farão jus à divisa de Cremonini: Intus ut libet, foris ut moris est - "interiormente como desejares, no exterior conforme o costume" (Delon, 2000, p. 25) -, a ponto de falarmos hoje numa "doutrina da dupla verdade", que "os conduz com frequência a sustentar teses diferentes segundo os lugares e os momentos, ou a

\footnotetext{
14 Garasse, n’A Curiosa Doutrina dos Espíritos Deste Tempo, acusa a dissimulação dos libertinos nas máximas II: “os belos espíritos só creem em Deus por decoro e por obediência ao Estado”; e VIII: “(...) é preciso evitar parecer ímpio e retirado, por temor de escandalizar as pessoas simples ou de se privar da proximidade dos espíritos supersticiosos" (Adam, 1964, pp. 41-42).

15 Michel Delon sugere que uma comparação da edição original do Roman Comique de Francion de Charles Sorel, de 1623, com as reedições de 1626 e 1633 permitiria "apreciar a mudança de tom que é a de toda uma época, mensurar os temores e a autocensura provocada por essa caça às bruxas” (Delon, 2000, p. 24).
} 
prudentemente desmentir em publicações suas audácias orais ou privadas" (ibid., p. 27).

A contrapartida necessária dessa prudência é o fato de que as ideias heterodoxas dos libertinos eruditos se furtam ao espaço público, e é aí que reside, ao menos teoricamente, sua diferença específica em relação aos iluministas. Com efeito, talvez seja possível apontar mais continuidades do que rupturas entre libertinismo erudito e Iluminismo quanto ao teor das ideias, especialmente no que concerne à formação de um ideário materialista. ${ }^{16} \mathrm{O}$ programa pedagógico das Luzes e a consequente necessidade de se pôr no espaço público, porém, marcam a diferenciação do Iluminismo.

Uma exposição esquemática, todavia, arrisca passar a ideia da existência de um ponto de inflexão único, evidência incontestável daquela "mudança estratégica" a que nos referimos acima. No entanto, como é frequente na história das ideias, a mudança nesse caso é gradual e não linear, sobretudo porque os autores que desejam se aventurar nessa empreitada precisam se avir com o fato de que o grau de publicidade e de exposição a que submetem seus escritos cresce na mesma proporção dos perigos da perseguição. Nos mais de cem anos transcorridos entre o libertinismo erudito da primeira metade do século XVII e a Enciclopédia de Diderot e D’Alembert, ícone máximo do Iluminismo, muita água rolou. ${ }^{17}$ Para o que nos interessa aqui, contudo, bastará registrarmos brevemente uma mediação nesse percurso, antes de retornarmos a Diderot.

\section{NOVAS ESTRATÉGIAS DE ESCRITA NAS ENTRELINHAS}

Assim como os libertinos eruditos, Bayle estava ciente da necessidade de ser prudente na disseminação de ideias heterodoxas, mesmo num ambiente relativamente livre como o de Roterdã. ${ }^{18}$ Relatando uma conversa privada, nos Pensamentos diversos sobre o cometa, de 1682, ele diz ter raciocinado com a liberdade de que

\footnotetext{
16 Cf. Olivier Bloch, L’héritage libertin dans le matérialisme des Lumières, in: Dix-huitième Siècle, n²4, 1992. 17 Uma história exaustiva desse processo, mesmo se restrita ao território francês, precisaria dar conta da vasta produção de manuscritos clandestinos que circulou com alcance mais ou menos amplo desde o fim do século XVI sous le manteau, isto é, passando secretamente de mão em mão. No que diz respeito ao objeto da reflexão proposta neste capítulo, a história desses manuscritos possui o interesse particular de revelar certa popularização da filosofia: “Os manuscritos filosóficos clandestinos não são textos como os outros. Eles mantêm uma relação particular com o espaço público e constituem um testemunho sobre a substância da história das ideias em sua relação com a história social do livro e o nascimento da opinião pública. Nesse sentido, a clandestinidade desses textos traduz uma relação particular entre a vida das ideias e o espaço público sob o Antigo Regime” (Anthony McKenna, Présentation du corpus / Introduction aux manuscrits clandestins).

18 Pierre Bayle (1647-1706), o "filósofo de Roterdã", foi professor de história e de filosofia na Academia protestante de Sedan (1675-1681) e, após seu fechamento por decreto de Luis XIV, na École Illustre de Roterdã (1681-1693). Dentre suas principais obras estão os Pensamentos diversos sobre o cometa (1682), o Comentário filosófico (1686-88) e o Dicionário histórico e crítico (1697), reputado como “a Bíblia do século XVIII”, na expressão de Émile Faguet. Bayle foi ainda o primeiro redator das Notícias da República das Letras, de 1684 a 1687.
} 
só se dispõe "quando não se é importunado nem pela presença do povo, nem pela de doutores fanáticos, dois tipos de pessoas com as quais devemos ter cuidado: 0 primeiro, por medo de abalar sua fé, e os outros por medo de se tornar objeto de suas ardentes perseguições" (Bayle, 2000, p. 248).

Bayle já havia praticado a dissimulação antes de sua chegada à Holanda em 1681. Por ocasião de sua estadia em Genebra, de 1670 a 1674, após uma reconversão ao protestantismo, ele se 'converteu' também ao cartesianismo - do qual tomaria suas distâncias anos depois - e, de volta à França em 1674, ensinou o aristotelismo na Academia protestante de Sedan, enquanto interiormente cultivava ideias cartesianas e malebranchistas (Israel, 2001). A prudência no trato com ideias consideradas perigosas não significou todavia o silenciamento do "filósofo de Roterdã", pois, como ele afirma nos Pensamentos diversos (\$91),

é necessário se conduzir com muita discrição e com muito cuidado quando se ataca
os erros da religião, e é por esse motivo que alguém disse, falando dessas coisas, que
existem muitas verdades que, não apenas não é necessário que o povo conheça, mas
é ainda conveniente que ele creia no contrário. Dificilmente deve haver algum ho-
mem de estado ou da igreja que não seja desse sentimento. Mas ainda assim digo
que, mesmo mantendo toda a circunspecção que a prudência cristã nos requer, de-
veria ser permitido trabalhar para o esclarecimento da verdade em todas as coisas
(Bayle, 2000, p. 116).

Para compreender a fundo o sentido dessas palavras, contudo, é indispensável ter em conta o tipo de discrição adotado por Bayle. Os Pensamentos diversos, como os demais livros anteriores ao Dicionário histórico e crítico, foram publicados anonimamente pelo editor Reinier Leers, a quem Bayle se associou logo de sua chegada a Roterdã. O nome do editor tampouco é fornecido, e o livro despista quanto ao local de sua publicação, indicando a falsa localidade de Colônia. Esses expedientes, como sabemos, eram comuns e não se diferenciam das práticas utilizadas desde o início do século por inúmeros autores. O que diferencia efetivamente as técnicas de dissimulação usadas por Bayle na escrita dos Pensamentos diversos é o fato de que ele se vale, por assim dizer, de uma máscara: o texto é apresentado sob a forma de um conjunto de onze cartas, datando de 1 de janeiro a 11 de outubro de 1681, escritas por um remetente que se identifica apenas como " $\mathrm{A}$ ", e destinadas a um teólogo da Sorbonne não nomeado. Passado o tumulto inicial, Bayle confessará na nota à terceira edição que tudo não passava de uma ficção e que, com a esperança de ver o livro publicado em Paris, procurou "assumir o estilo de um Católico Romano e imitar a linguagem e os elogios do Monsieur de Visé em relação aos assuntos estatais" (Bayle, 2000, p. xxvi).

Ditas por um escolástico que se dirige a um teólogo da Sorbonne, escrevendo com "aquele ar livre que alguém se permite quando escreve a um amigo" (ibid., p. 
8), as ideias nada ortodoxas contidas no livro deveriam soar mais amenas. A persona de que Bayle se vale, com efeito, não se restringe à caracterização inicial do personagem-autor, mas molda o estilo da escrita e até mesmo a linha argumentativa do texto: o autor católico de Bayle "não solicita outro juiz além da teologia, e pretende usar, contra o presságio dos cometas, as mesmas armas pertencentes à piedade e à religião que têm sido usadas até agora em favor desses presságios" (ibid., p. 5).

Com a licença conferida pela autoridade dos interlocutores e pelo tom íntimo, os Pensamentos diversos, para além do ataque às superstições ligadas à passagem do cometa, defendem sem meias palavras a possibilidade de que ateus possam ser virtuosos (\$133) e de que uma sociedade de ateus possa ser bem-ordenada, e que os idólatras - com os quais muitos cristãos possuem inúmeras semelhanças - se encontram numa situação muito pior que a dos ateus diante de Deus, e até os superam no crime de lesa-majestade (\$132). Além disso, o livro mostra que as opiniões professadas pelos homens não determinam sua conduta ( $\$ 136)$, o que desarmava "a estratégia polêmica de Garasse e de seus semelhantes" de vincular qualquer comportamento fora da norma da ortodoxia à libertinagem e ao ateísmo, já que "os piedosos cristãos podem agir tão mal quanto os ateus podem agir virtuosamente" (Delon, 2000, pp. 28-29).

Uma estratégia semelhante de escrita e de publicação seria utilizada por Bayle no Comentário filosófico, cujas quatro partes foram publicadas entre $1686 \mathrm{e}$ 1688. O livro, que formula a ideia de uma tolerância universal, é apresentado como a tradução francesa do trabalho de um inglês chamado Jean Fox de Bruggs, uma espécie de "quaker sociniano" (McKenna, 2013, p. 1). Aqui, novamente, o expediente da máscara se presta não só à proteção contra a perseguição, mas se coaduna à intenção de tornar a argumentação mais palatável e o leitor mais receptivo:

as premissas de Bayle são tais que mesmo os cristãos mais inclinados a perseguir teriam de aceitar. Como ele diz com frequência, os argumentos não têm valor se "recolocam a questão", isto é, se de algum modo assumem o que deveriam provar. A marca distintiva do estilo intelectual de Bayle é seu esforço enérgico para argumentar a partir de "princípios comuns" aceitáveis por pessoas a cujas práticas ele se opunha profundamente (Kilcullen e Kukathas, in: Bayle, 2005, p. xxi).

É com o Dicionário histórico e crítico, porém, que Bayle tenta sua estratégia mais ousada. A obra de 1697 é a primeira em que consta o nome de Bayle como autor. Sua intenção inicial era novamente manter-se no anonimato, mas, "por causa de problemas legais causados pelos editores do Dicionário de Moreri" (Bayle, 1965, p. xx), foi necessário que o autor fosse identificado expressamente. Na página de rosto constavam ainda o nome de Leers como editor, a indicação de Roterdã 
como origem e a inscrição "com privilégio"; e nas duas páginas seguintes lia-se, em holandês, o texto de concessão do privilégio, assinado pela autoridade local. Tratava-se, enfim, de uma publicação oficial. Diante da exposição completa de sua identidade como autor era preciso se proteger de alguma outra maneira contra as investidas de censores e perseguidores como Jurieu. Na verdade, foi porque os expedientes que, supostamente, poderiam protegê-lo já haviam sido empregados na escrita do Dicionário que Bayle pôde dar a ele a exposição irrestrita de uma publicação oficial. ${ }^{19}$

O verbete Spinoza contém talvez os melhores exemplos do tipo de expediente a que nos referimos e foi, em todo caso, um dos pontos mais controversos do Dicionário. Nele, Bayle critica o que ele crê ser o núcleo do spinozismo, a saber, a doutrina da substância única, equivalendo tanto à natureza quanto a Deus, com seus infinitos atributos. A nota $N$, uma das mais longas do verbete, é interposta para comentar essa hipótese, que veio à luz na Opera Posthuma de Spinoza, para Bayle a "mais monstruosa hipótese que se poderia imaginar, a mais absurda e a mais diametralmente oposta às noções mais evidentes de nossa mente" (Bayle, 1965, pp. 296-297). Como consequência dessa hipótese, todos os corpos existentes no mundo seriam modificações dessa substância enquanto extensa, e todas as almas dos homens seriam suas modificações enquanto ela pensa.

Coerente com seu estilo argumentativo desde as primeiras obras, Bayle toma como ponto de partida os pressupostos de nossa experiência espontânea, vendo as individualidades como substâncias distintas. Spinoza teria uma resposta a essa objeção, que já lhe havia sido feita antes de Bayle, dizendo que é preciso atentar para a doutrina dos modos de conhecimento: se para a imaginação, que conhece superficialmente, a diversidade aparece como essencialmente distinta, o intelecto, por outro lado, é capaz de conceber que a distinção é apenas aparente e que a unicidade da substância é que é real. "Bayle de algum modo reifica em objetos distintos e incompatíveis o que Spinoza concebe como diferentes gêneros de conhecimento de uma mesma e única realidade" (Gros, in: Bayle, 2001, p. 517). O nervo da questão está na maneira como se compreende a relação entre a substância e seus modos, como o próprio Bayle indica ao se defender da acusação de que não teria entendido corretamente a doutrina spinozista: "se não se compreende o que ele

\footnotetext{
19 A hesitação inicial em estampar seu nome à frente do Dicionário parece não ter tido relação direta com a necessidade de se proteger e, a julgar pelo que diz o autor no prefácio, a despeito da censura, o anonimato era para ele uma opção intelectual: "não condeno aqueles que se nomeiam no topo de seus trabalhos, mas sempre tive uma antipatia secreta por isso" (apud Bartlett, in: Bayle, 2000, p. xxvi; sobre o sentido do anonimato na escrita do Dicionário, cf. Antony McKenna, Les masques de Pierre Bayle: pratiques de l'anonymat). De fato, a intenção de Bayle parece ter sido desde o início a de publicar o Dicionário legalmente, com o devido privilégio, como atesta o Projeto de um dicionário crítico redigido por ele e posto em circulação por Leers, em 1692, para sondar o interesse do público.
} 
quer dizer com isso, sem dúvida é porque ele deu a essas palavras um significado completamente novo, sem alertar o leitor" (Bayle, 1965, p. 304).

A condenação radical do sistema de Spinoza, contudo, não é o sentido profundo do verbete $;^{20}$ não são as discussões técnicas e metafísicas que motivam Bayle pessoalmente. O que o intriga é saber o que teria levado um espírito profundo e brilhante como o de Spinoza a formular teses tão absurdas - se damos por aceito o absurdo das teses. A hipótese de Bayle é a de que Spinoza teria sido levado a esses absurdos por não se conformar com outros tantos absurdos que eram ensinados pela teologia:

Ele só se lançou nesse precipício por não ser capaz de compreender que a matéria é eterna e diferente de Deus, nem que é produzida a partir do nada, nem que uma mente infinita e supremamente livre, criadora de todas as coisas, pudesse produzir uma obra tal como o mundo. (...) Essas são três dificuldades que obrigaram Spinoza a buscar um novo sistema no qual Deus não seria distinto da matéria e no qual Ele age necessariamente e em acordo com a extensão total de seus poderes, não fora de si, mas em si mesmo (Bayle, 1965, pp. 314-315).

Bayle então convida o leitor a pesar imparcialmente as três dificuldades que Spinoza quis evitar e "as extravagantes e abomináveis consequências da hipótese que ele adotou" (ibid., p. 315). Ainda que o leitor considerasse que as dificuldades teóricas colocadas pela hipótese de Spinoza equivalem às que ele quis contornar, o fiel da balança em favor da hipótese cristã seria, por um lado, a longa e numerosa adesão dos homens, isto é, a tradição e o costume, contra as inovações de um aventureiro; e, por outro, os benefícios práticos oferecidos pela hipótese cristã, com a promessa de uma vida eterna e o conforto diante das angústias nesta vida; a partir do que Bayle conclui: "a hipótese ordinária é então preferível à outra" (ibid., p. 316). A escolha de Spinoza, portanto, "não é a de um homem de bem ou de um homem de espírito" (ibid., p. 315).

Jean-Michel Gros sublinha o tom suspeito dessa argumentação. Ora, os Pensamentos diversos se detêm particularmente sobre esses pontos, atacando "a autoridade da tradição" (\$7) e afirmando que "não se deve julgar em filosofia pela pluralidade de vozes" (\$48) (Bayle, 2000, p. 22; p. 66). Ademais, é estranho que Spinoza não seja "homem de bem" ou "homem de espírito" aos olhos de Bayle, que gastou sua pena em boa parte do verbete para defender o caráter do autor da Ética, atestando se tratar de "um homem avesso a qualquer constrangimento do espírito e grande inimigo da dissimulação" (Bayle, 1965, p. 290), além de destacar sua honestidade intelectual ao buscar elucidar os mistérios que o cristianismo obscurecia.

20 Seguimos aqui a interpretação de Jean-Michel Gros em sua apresentação do verbete (Cf. Jean-Michel Gros, Présentation de l'article "Spinoza”, in: Bayle, 2001). 
A suspeita se agrava se recordamos que o Dicionárioem mais de uma ocasião sugere a inviabilidade de uma explicação do mal no mundo a partir de uma vontade livre do criador, e flerta com explicações materialistas como a de Crisipo, que fornecia "uma espécie de genealogia natural da organização do corpo humano" (Gros, in: Bayle, 2001, p. 521), dando conta do fato de que a delicadeza de certas estruturas anatômicas da cabeça era requerida para a fineza das funções cognitivas, mas, ao mesmo tempo, abria um flanco às doenças e acidentes. A essa explicação "tão conforme ao bom senso" (ibidem), Bayle contrapõe - segundo Gros, ironicamente - a doutrina cristã de que todos os males provêm do pecado original, comentando: "não penso que um pagão poderia ter dito nada mais razoável na ignorância em que se encontrava da queda do primeiro homem, queda da qual só pudemos saber pela revelação, e que é a causa de todas as nossas misérias" (Bayle, 2001, p. 521). A desproporção no poder explicativo das duas teses parece falar por si mesma.

Do mesmo modo, o jogo polêmico com Straton, outra figura do ateísmo naturalista na Antiguidade, já no Dicionário, mas sobretudo na Continuação dos Pensamentos diversos, se presta à constituição de "uma espécie de 'ateísmo razoável' que, uma vez purgado das hipóteses excessivas do spinozismo (...), vai lhe oferecer [a Bayle], em todas as circunstâncias, uma bateria de argumentos racionais que podem ser opostos às dificuldades da 'hipótese cristã'" (Gros, in: Bayle, 2001, p. 521). Isso posto, é plausível considerar então que a discordância de Bayle em relação a Spinoza não é da ordem de uma oposição completa, nem em termos filosóficos, nem em termos morais.

Essa objeção diz respeito, talvez, menos ao conteúdo que à ambição metafísica revelada pelo próprio sistema. Spinoza aspira a uma explicação total e totalmente racional do mundo. (...) Assim, o erro filosófico de Spinoza é, primeiramente, aos olhos de Bayle, o de, mais que qualquer outro, ter feito "o dogmático". Não é necessário, com efeito, para quem quer escapar da armadilha da ortodoxia, buscar opor-lhe um sistema antagonista completo. Arrisca-se, por outros meios, a prolongar seus efeitos mais perniciosos (Gros, in: Bayle, 2001, p. 523).

A dissimulação de Bayle através de todos esses expedientes talvez não tenha obtido o sucesso que ele próprio desejaria, pois não foi suficiente para poupá-lo de numerosos transtornos. Por outro lado, o fato de que, ao longo de toda a sua fortuna crítica, se discutiu - e ainda hoje se discute - quais eram suas reais intenções parece indicar que aqueles expedientes produziram certa ambiguidade irredutível, o que pode ter servido de trunfo ao autor na hora de se defender de acusações de impiedade. De todo modo, a difusão de ideias heterodoxas, sobretudo com o 
Dicionário, se beneficiou desses expedientes e ganhou um alcance que talvez não tenha comparação à época a não ser em Fontenelle.

Retomando então a perspectiva colocada pela reflexão de Diderot, cujo fio seguimos, poderíamos dizer, de modo bastante esquemático, que nos libertinos eruditos a distinção entre um ensinamento popular e uma doutrina reservada aos filósofos ditava exteriormente o sentido do texto: ou ele seria exotérico, escrito em acordo com a ortodoxia, e portanto seu autor não teria nada a temer com sua publicação, como é o caso, por exemplo, das obras apologéticas de Charron; ou seria esotérico, expondo ideias heterodoxas abertamente, mas de circulação restrita às pessoas de confiança, sob forma manuscrita ou em impressões clandestinas de pequena tiragem. Por sua vez, as estratégias de escrita nas entrelinhas, para voltarmos à expressão de Strauss, levam a distinção entre exotérico e esotérico para o interior do próprio texto, cabendo ao leitor "a tarefa de desembaraçar a verdade de sua exposição poética ou dialética" (Strauss, 1988, p. 35).

A perseguição, então, dá origem a uma técnica peculiar de escrita, e com isso a um tipo peculiar de literatura, no qual a verdade a respeito de coisas cruciais é apresentada exclusivamente nas entrelinhas. Essa literatura não é destinada a todos os leitores, mas somente aos confiáveis e inteligentes. Ela possui todas as vantagens da comunicação privada sem possuir sua principal desvantagem - alcançar apenas as relações do autor. Ela possui todas as vantagens da comunicação pública sem possuir sua principal desvantagem - a pena capital para o autor. Mas como pode alguém realizar o milagre de falar para uma minoria em uma publicação, silenciando para a maioria dos leitores? (Strauss, 1988, p. 25).

A resposta a essa questão é simplesmente a de que apenas os leitores inteligentes compreenderão o que está dito nas entrelinhas. No entanto, parece plausível pensar que podem haver leitores não confiáveis, mas suficientemente inteligentes para compreender o sentido oculto de um texto desse tipo, podendo então denunciar o autor às autoridades. Assim, segundo Strauss, haveria um pressuposto socrático nesses autores, no sentido de crer que conhecimento é virtude, e que, portanto, um leitor suficientemente inteligente para ler nas entrelinhas não poderia ser um indivíduo cruel.

Esse 'socratismo' é um dos motivos que autorizaria, talvez, falarmos em um otimismo das Luzes. Mas há ainda um outro, anterior a esse, e que traça de modo mais nítido a linha demarcatória entre libertinismo e Iluminismo ou, nas palavras de Strauss, entre autores pré-modernos e modernos. Com efeito, em seu ensaio sobre a arte da escrita ele se refere a "um tipo anterior de escritor" em termos que se conformam à caracterização de Charron e dos libertinos eruditos vista acima, enquanto, na outra ponta, pinta o quadro do filósofo iluminista que vemos nascer a partir das estratégias de escrita nas entrelinhas: 
A atitude adotada pelas pessoas em relação à liberdade de discussão pública depende de modo decisivo do que elas pensam a respeito da educação popular e de seus limites. De um modo geral, filósofos pré-modernos foram mais tímidos que os modernos nesse quesito. A partir de meados do século dezessete um número cada vez maior de filósofos heterodoxos, que haviam sofrido com a perseguição, publica seus livros não apenas para comunicar seus pensamentos, mas também porque desejam contribuir para a abolição da perseguição enquanto tal. (...) Eles aspiravam por um tempo em que, como resultado do progresso da educação popular, uma liberdade de expressão quase completa fosse possível, ou - exagerando para deixar mais claro - um tempo em que ninguém sofresse nenhum mal por ouvir qualquer verdade. Eles escondiam suas opiniões somente na medida necessária para se proteger tanto quanto possível da perseguição; se fossem mais sutis que isso, fracassariam em seu propósito, que era o de esclarecer um número cada vez maior de pessoas que não fossem potenciais filósofos (Strauss, 1988, p. 33).

Esse otimismo, ainda tímido e irregular em Bayle, é mais sensível em Fontenelle e aparece com plena nitidez no lema da Enciclopédia de Diderot e d'Alembert: "mudar a maneira comum de pensar" (Diderot, 1755, p.642v). Esse percurso, entretanto, não se fará só de luzes: antes de chegar a imprimir a Enciclopédia, em cujo quinto volume figura a célebre divisa do Iluminismo, Diderot vivenciou e meditou sobre o dilema do escritor ilustrado numa era de perseguição.

\section{FILOSOFIA E MUNDANIDADE}

A partição dos caminhos humanos, tal como aquela apresentada por Cleóbulo e recolhida por Aristo, já havia sido desenhada - de forma alegórica ou não - por inúmeros autores, filósofos ou homens da igreja, desde muito antes de Diderot, e constituía já um lugar-comum à época da redação de $O$ passeio do cético. Vimo-la na tripartição de Charron, indicando a existência de três tipos de sabedoria, e poderíamos acrescentar a essa lista a alegoria de Zacharie de Lisieux, que, por sua vez, é uma paródia da carte de Tendre. ${ }^{21}$

O passeio do cético é, de certo modo, uma versão irônica dessas narrativas. Se cotejamos a tripartição de Diderot com a de Charron - para insistirmos em nossa tentativa de dar sentido à passagem do libertinismo erudito ao Iluminismo

\footnotetext{
21 O mapa de Tendre é a representação topográfica e alegórica de um país imaginário chamado Tendre. Aludido pela primeira vez no romance Célie, histoire romaine (1654), de Madeleine de Scudéry (1607-1701), é retomado em diversas ocasiões nos anos seguintes. O mapa apresenta os diferentes caminhos e etapas da vida amorosa, e participou da moda literária da Preciosité. O frade franciscano Zacharie de Lisieux (1596-1661) fez publicar em 1660, sob o pseudônimo de Louys Fontaines, sieur de Saint Marcel, uma paródia do mapa intitulada Relato do país de Jansénie, em que se trata das singularidades que aí se encontra, dos hábitos, costumes e religião de seus habitantes, atacando o jansenismo. Uma edição revista e aumentada pelos jesuítas, de 1688, trazia um título autoexplicativo: O anti-fantasma do jansenismo, ou A nova descrição do país de Jansénie com seus confins, a Calvinie, a Libertinie, a Désespérie e o mar Prolyse ou Mar da Presunção, tudo representado em um mapa geral dessas quatro províncias com sua explicação, em que se trata das singularidades que aí se encontra, dos hábitos, costumes e religião de seus habitantes.
} 
-, vemos que as duas se assemelham em virtude dos elementos dispostos nas três vias: O passeio do cético é composto pelas alamedas dos espinhos (religião) e dos castanheiros (filosofia), e pelo jardim das flores (o mundo ou a galanteria e a libertinagem); assim como as três sabedorias de Charron são a sabedoria divina, a humana e a mundana. O que afasta os dois autores, contudo, é a hierarquização das partes e o valor conferido a cada uma delas: enquanto Charron aponta a sabedoria divina como a mais elevada, seguida de perto pela sabedoria humana, e despreza a sabedoria mundana como uma 'falsa sabedoria', Diderot satiriza mordazmente a religião e, ainda que conceda importância maior à filosofia, revela que mesmo os filósofos vez ou outra dão suas escapadas até o jardim das flores. A filosofia, sempre entre dois extremos, ora se inclina a um, ora a outro.

É possível analisar esse balanço da filosofia sob dois pontos de vista. Primeiro, ele diz respeito ao modo como os autores pensam a filosofia moral: como uma moral ascética, segundo a tradição da Igreja, ou, no outro extremo, como uma moral hedonista, voltada inteiramente ao sensível, passando pelas várias gradações que medeiam esses dois polos. Teoricamente, tanto Charron quanto Diderot fazem da filosofia um saber natural e, embora o cônego de Condom seja certamente bem mais pudico que Diderot, o que vemos em Da sabedoria é a proposta de uma moral secularizada. Em termos práticos, porém, a ênfase de Charron recai sobre o freio das paixões em vista da conquista de um equilíbrio espiritual, enquanto para Diderot o equilíbrio é encontrado positivamente, na efetivação das paixões, e não negativamente, como na moral ascética, criticada com veemência nos Pensamentos filosóficos. ${ }^{22}$ É a variedade das paixões, seu uso, por assim dizer, promíscuo, o que pode conduzir a um equilíbrio do espírito. Por essa via, descobriremos um Diderot filiado à tradição da libertinagem de costumes, autor de um romance libertino, As joias indiscretas.

O balanço da filosofia entre o divino e o mundano pode, no entanto, ser considerado de um segundo ponto de vista, através do qual reencontraremos a tese de Strauss. Entendido como popular ou comum, tal como na designação de Charron, o horizonte do mundano se confunde com o do exotérico. Nesse sentido, é significativo que a filosofia, já na tripartição dos caminhos n'O passeio do cético, inclinese na direção do mundano, do qual ela se afasta em Charron. A Enciclopédia, com efeito, será por sua própria natureza uma empresa exotérica, na qual "o homem do povo e o erudito poderão instruir-se igualmente" (Diderot, 1755, p. 637r). Colas

22 “É o cúmulo da loucura propor-se a ruína das paixões. Belo projeto o de um devoto que se atormenta como um fanático para não desejar nada, não amar nada, não sentir nada, e que acabará por se tornar um verdadeiro monstro se obtiver sucesso!” (Diderot, 1994, p. 20). 
Duflo recorda que o primeiro emprego de que se tem notícia da palavra 'filósofo' em Diderot ocorre na tradução de $A$ história de Grécia, de Temple Stanyan, em 1743. Diderot a utiliza em substituição à expressão wise man, do original inglês. $O$ trecho em questão se refere na verdade a Prometeu, cuja figura é a imagem do filósofo com a qual Diderot mais se identifica, "pois ele é o indiscreto supremo, aquele que revela aos homens o maior segredo, que deles era ocultado pelos deuses, aquele que esclarece, em todos os sentidos do termo" (Duflo, 2003, p. 21).

Mas o impulso exotérico do esclarecimento não pode se resumir, é claro, às declarações de princípios e à mera disponibilidade física do texto ao grande público. Para que ele seja efetivo é preciso que a filosofia possua uma linguagem acessível; que, por assim dizer, fale a língua do povo: "não é suficiente revelar, é preciso ainda que a revelação seja inteira e clara" (Diderot, 1994, p. 582), dirá Diderot nos Pensamentos sobre a interpretação da natureza, em 1753. "Apressemo-nos", ele continua, "em tornar a filosofia popular. Se queremos que os filósofos avancem, aproximemos o povo do ponto em que estão os filósofos" (ibidem). É o que Diderot buscaria fazer, por exemplo, através da escrita de diálogos e contos filosóficos. Nesse sentido, Sócrates é outra figura que aparece como modelar, tanto por sua busca incessante da verdade quanto por sua maneira de ensiná-la, "com candura e modéstia, com facilidade e afabilidade, temperando a secura de seus preceitos com o sal do gracejo; pois ele não ignorava que o meio mais seguro de persuadir é agradar" (Diderot apud Duflo, 2003, p. 22).

Essa postura reflete, sem dúvida, o espírito de uma época. A passagem da França de Luís XIV àquela da Regência equivaleu, para os franceses, a desfazer-se de um pesado fardo. "Os hábitos do Regente", famoso por suas orgias, e "depois os de Luís XV, que estabelece amantes oficiais na corte, são imitados pelos grandes aristocratas antes de se difundirem amplamente pela sociedade" (Delon, 2000, p. 31). Associada a isso, a mudança da corte de Versalhes para Paris significou na prática uma dissolução do estilo e dos costumes palacianos e uma efervescência da vida cultural urbana parisiense. Não se poderia menosprezar a importância desse ambiente para Diderot, inclusive no que concerne à escrita. Ao fim de suas Observações a respeito da Carta sobre o homem e suas relações, de Hemsterhuis, Diderot elogia ao autor a beleza e fineza de suas ideias, mas lamenta que elas não tenham sido expressas em uma linguagem mais adequada: "se tivésseis vivido dois ou três anos em nossa capital, em ligação íntima com meus amigos, teríeis encontrado uma língua corrente, sempre pronta a se prestar às vossas ideias; e vossa obra poderia ter sido infinitamente mais agradável e mais fácil de ler" (Diderot, 1994, p. 770). 
A tentativa do filósofo de ir ao mundo ou de, como dizia Strauss, trabalhar pela "educação popular"; numa palavra, o esforço de urbanização da filosofia deverá, todavia, ser contrabalançado pela prudência em relação aos perigos de uma exposição excessiva. Nas Observações sobre Hemsterhuis, já mencionadas, ao elogio da leveza e urbanidade da escrita parisiense, se segue um porém: "mais lido e melhor compreendido neste país, teríeis sido lançado em uma perseguição violenta. Assim, feitas as contas, teríeis trocado o repouso pela consideração" (ibidem). Essas palavras, escritas entre 1773 e 1774, parecem retomar as de Cleóbulo no discurso preliminar a $O$ passeio do cético, pelas quais iniciamos nosso percurso. Elas visavam dissuadir Aristo justamente da ideia de popularizar a 'filosofia local' que Cleóbulo desenvolvera em seu jardim e, diante da obstinação do amigo, Cleóbulo acrescentava: "mais vale ser mau autor em repouso, que bom autor perseguido" (ibid., p. 77). A resposta de Aristo, dizendo que tentaria "fazer um bom livro e evitar a perseguição" (ibidem), exprime a miragem do escritor das Luzes, isto é, a conquista de um equilíbrio fino entre clareza, leveza, aprazibilidade, de um lado, e sutileza, sugestão, evasão, de outro. Um erro de dosagem pode comprometer a pretensão iluminista da obra, ou a segurança do autor.

Em julho de 1749 Diderot seria encarcerado em Vincennes, onde permaneceria por mais de três meses, acusado da autoria da Carta sobre os cegos e de outros textos contrários à religião, aos costumes e ao Estado. A liberdade só lhe foi restituída mediante a promessa de "não fazer nada no futuro que possa ser contrário, na menor coisa, à religião e aos bons costumes" (Wilson, 2012, p. 140). Ironicamente, a observância dessa promessa fez com que a obra ulterior de Diderot se cindisse em uma parte exotérica, destinada à publicação oficial e 'autorizada', e uma outra parte esotérica, que ele publicaria sobretudo na Correspondência literária, a revista editada por Melchior Grimm e que circulava apenas entre aristocratas e eruditos europeus fora da França. Não se tratou, porém, de um retorno à 'doutrina da dupla verdade': mesmo as obras destinadas ao grande público conteriam ainda ideias heterodoxas ou radicais, mais ou menos bem escondidas nas entrelinhas, como na Enciclopédia, com seu jogo de remissões. O próprio autor, por fim, considerou ter tido nisso algum sucesso: "quanto a mim, salvei-me pelo tom irônico mais desatado que pude encontrar, pelas generalidades, pelo laconismo e pela obscuridade" (Diderot, 1994, p. 770).

\section{REFERÊNCIAS}

ADAM, Antoine. Les libertins au XVIIe siècle. Paris: Buchet/Chastel, 1964. 
BAYLE, Pierre. A Philosophical Commentary on These Words of the Gospel, Luke 14.23, "Compel Them to Come In, That My House May Be Full". Trad.: John Kilcullen e Chandran Kukathas. Indianápolis: Liberty Fund, 2005.

BAYLE, Pierre. Historical and Critical Dictionary - Selections. Trad.: Richard Popkin. Indianápolis: Bobbs-Merrill, 1965.

BAYLE, Pierre. Pour une histoire critique de la philosophie - choix d'articles philosophiques du Dictionnaire historique et critique. Paris: Honoré Champion, 2001.

BAYLE, Pierre. Various thoughts on the occasion of a comet. Trad.: Robert Bartlett. Nova Iorque: State University of New York Press, 2000.

BLOCH, Olivier. L'héritage libertin dans le matérialisme des Lumières. Dix-huitième Siècle, $\mathrm{n}^{\circ} 24$, 1992. Le matérialisme des Lumières. pp. 73-82.

CAVAILLÉ, Jean-Pierre. Les Déniaisés. Irréligion et libertinage au début de l'époque moderne, Paris: Garnier, 2013.

CAVAILLÉ, Jean-Pierre. Libertinage, irréligion, incroyance, athéisme dans l'Europe de la première modernité (xvie-xviie siècles). Une approche critique des tendances actuelles de la recherche (1998-2002). Les Dossiers du Grihl [En ligne], 2007. Disponível em: https://journals.openedition.org/dossiersgrihl/279. Último acesso em: 16 de junho de 2021.

CHARLES-DAUBERT, Françoise. Les libertins érudits en France au XVII siècle, Paris: Presses Universitaires de France, 1998.

CHARRON, Pierre. De la sagesse. Trois livres. T. 1. Paris, 1827. Fonte: gallica.bnf.fr / Bibliothèque nationale de France. Último acesso em: 16 de junho de 2021.

CHARRON, Pierre. Pequeno Tratado da Sabedoria. Trad.: Maria Célia Veiga França. Belo Horizonte: Editora UFMG, 2005.

DARNTON, Robert. Censors at work: how states shaped literature. Reino Unido: British Library, 2014.

DELON, Michel. Le savoir-vivre libertin. Paris: Hachette, 2000.

DIDEROT, Denis. Encyclopédie, ou dictionnaire raisonné des sciences, des arts et des métiers, vol. V (1755). Disponível em: http://enccre.academiesciences.fr/encyclopedie/article/v5. Último acesso em: 16 de junho de 2021.

DIDEROT, Denis. Oeuvres, t. 1 Philosophie. Paris: Robert Laffont, 1994.

DUFLO, Colas. Diderot philosophe. Paris: Honoré champion, 2003.

ISRAEL, Jonathan. The radical enlightenment. Nova Iorque: Oxford University Press, 2001.

LA MOTHE LE VAYER, François de. Quatre dialogues faits à l'imitation des anciens. Paris, 1633. Fonte: gallica.bnf.fr / Bibliothèque nationale de France. Último acesso em: 16 de junho de 2021.

LITTRÉ, Émile. Dictionnaire de la langue française. Paris: L. Hachette, 1873-1874. Disponível em: http://www.littre.org. Último acesso em: 16 de junho de 2021. 
McKENNA, Antony. Les masques de Pierre Bayle: pratiques de l'anonymat. Littératures Classiques - janeiro 2013.

PINTARD, René. Le Libertinage érudit dans la première moitié du XVIIe siècle. Genève, Paris: Slatkine, 1983.

POPKIN, Richard. The history of ceticism from Savonarola to Bayle. Nova Iorque: Oxford University Press, 2003.

SEGUIN, Maria Susana. La littérature philosophique clandestine et l'imposture: introduction. In: La Lettre clandestine. Classiques Garnier; no prelo. Disponível em: https://hal.archives-ouvertes.fr/hal-03168579. Último acesso em: 16 de junho de 2021.

STENGER, Gerhardt. Sur la chronologie des premières oeuvres de Diderot, in: Dixhuitième siècle, $\mathrm{n}^{\circ} 25$, 1993. L'Europe des Lumières. pp. 411-421.

STRAUSS, Leo. Persecution and the Art of Writing. Chicago: The University of Chicago Press, 1988.

VIAU, Théophile de et al. Théâtre du XVIIe siècle I. Paris: Gallimard, 1975.

WILSON, Arthur. Diderot. São Paulo: Perspectiva, 2012. 